MYU Tokyo

S \& M 1237

\title{
Amperometric Nitrite-Ion Sensor Based on Electrodeposited Sm-Based Perovskite-Type Oxide Thick-Film Electrode
}

\author{
Takahiro Yatsunami, Satoko Takase, and Youichi Shimizu* \\ Department of Applied Chemistry, Kyushu Institute of Technology, \\ 1-1 Sensui-cho, Tobata, City of Kitakyushu, Fukuoka 804-8550, Japan
}

(Received September 30, 2015; accepted March 7, 2016)

Keywords: perovskite-type oxide, nitrite-ion sensor, carbon-felt electrodes, amperometric, electrophoretic deposition

Perovskite-type oxide $\mathrm{SmBO}_{3}(B=\mathrm{Cr}, \mathrm{Mn}, \mathrm{Fe}, \mathrm{Co})$ powders were prepared by a polymer precursor method at $750{ }^{\circ} \mathrm{C}$ and systematically investigated for electrochemical sensing properties for $\mathrm{NO}_{2}^{-}$. The $\mathrm{SmBO}_{3}$-modified carbon-felt electrodes could be prepared by an electrophoretic deposition (EPD) method without sintering. Among the oxide deposited electrodes, the $\mathrm{SmFeO}_{3}$ modified electrode showed the highest sensitivity to $\mathrm{NO}_{2}^{-}$with $11.9 \mathrm{~mA} \mathrm{M}{ }^{-1} \mathrm{~cm}^{-2}$ and a linear sensing range between $5.0 \times 10^{-5}$ and $1.0 \times 10^{-3} \mathrm{M}$ at $+0.85 \mathrm{~V}$ vs $\mathrm{Ag} / \mathrm{AgCl}$ with high selectivity for $\mathrm{NO}_{2}^{-}$and no response to most other anions. A good correlation was observed between electrochemical activity toward nitrite-ion oxidation and oxygen adsorption properties of the oxides.

\section{Introduction}

It is known that nitrite ion $\left(\mathrm{NO}_{2}^{-}\right)$reacts easily with proteins to produce carcinogenic $\mathrm{N}$-nitrosamines which cause esophageal cancer and methemoglobinemia in vivo. Although it is used as an antioxidant for foods and beverages, nitrite ion itself is high toxic, and it should be at a concentration less than $65 \mu \mathrm{M}$ in drinking water according to the standards of the World Health Organization (WHO). It is also well known that $\mathrm{NO}_{2}^{-}$causes eutrophication in closed water systems. Thus, quantitative analysis of $\mathrm{NO}_{2}^{-}$has become very important. Thus far, nitrite ion is typically analyzed by a spectrophotometric method ${ }^{(1,2)}$ or by ion chromatography, but these methods are complicated and not suitable for on-site monitoring. In contrast, electrochemical methods have aroused considerable interest as possibilities for the design of compact and low-cost ion sensors. As electrochemical $\mathrm{NO}_{2}^{-}$sensing materials, various metal complexes ${ }^{(3,4)}$ as ionophores for potentiometric sensors, and carbon nanomaterials, ${ }^{(5,6)}$ metal nanomaterials, ${ }^{(7-12)}$ metal organic complexes, ${ }^{(13,14)}$ and conducting polymers ${ }^{(15)}$ for amperometric sensors have been reported. Oxidebased $\mathrm{NO}_{2}^{-}$sensing materials, such as hollow $\mathrm{Fe}_{2} \mathrm{O}_{3}$ nano-polyhedrons, ${ }^{(16)} \mathrm{Fe}_{2} \mathrm{O}_{3}$ nanoparticledecorated reduced graphene oxide nanosheets, ${ }^{(17)}$ and nanoporous $\mathrm{Fe}_{2} \mathrm{O}_{3}-\mathrm{CoO}$ composites ${ }^{(18)}$ have been developed. These sensors revealed a remarkable interaction between elemental iron and $\mathrm{NO}_{2}^{-}$. These results indicated that iron-based mixed oxides might be suitable candidate materials

"Corresponding author: e-mail: shimizu.youichi366@mail.kyutech.jp 
for $\mathrm{NO}_{2}^{-}$sensing. We have proposed various electrochemical ion sensors for the hydrogen phosphate ion ${ }^{(19)}$ and hydrogen peroxide ${ }^{(20)}$ based on the considerable electrocatalytic properties of perovskite-type oxides. It has also been reported that Sm-based perovskite-type oxides showed high sensing abilities among the lanthanoids ( $\mathrm{La}, \mathrm{Nd}, \mathrm{Sm}, \mathrm{Gd}$, and Dy). ${ }^{(21,22)}$ In this study, we have systematically evaluated electrochemical catalytic activities of perovskite-type oxide $\operatorname{Sm} B \mathrm{O}_{3}(B=$ $\mathrm{Cr}, \mathrm{Mn}, \mathrm{Fe}, \mathrm{Co}$ )-modified carbon-felt electrodes prepared by electrophoretic deposition (EPD) for amperometric $\mathrm{NO}_{2}^{-}$sensing. The $\mathrm{SmFeO}_{3}$ modified carbon-felt electrode showed the highest $\mathrm{NO}_{2}^{-}$ sensing properties; these properties were related to the amount and the strength of adsorbed oxygen on the surface of the $\mathrm{SmFeO}_{3}$.

\section{Experimental}

\subsection{Preparation of perovskite-type oxide powders}

Perovskite-type oxide $\mathrm{SmBO}_{3}$ powders were prepared by a polymer precursor method. ${ }^{(23,24)}$ A $10 \mathrm{mmol}$ quantity of metal ( $\mathrm{Sm}, \mathrm{Cr}, \mathrm{Mn}, \mathrm{Fe}, \mathrm{Co}$ ) nitrate of reagent grade was dissolved in $50 \mathrm{~mL}$ of ethylene glycol (EG), which was mixed with $40 \mathrm{mmol}$ of acetylacetone (AcAc) as a coordinating agent and $7.5 \mathrm{wt} \%$ polyethylene glycol (PEG: MW 200) as a polymer additive, until a viscous sol was formed. These polymer precursor solutions were dried in ambient air to form xerogel powders, which were then heat-treated at $750{ }^{\circ} \mathrm{C}$ for $2 \mathrm{~h}$. The crystal structures of the powders obtained were elucidated by X-ray diffraction (XRD) analysis using $\mathrm{CuK} \alpha$ radiation $(\lambda=0.15405 \mathrm{~nm})$ (X-ray diffraction spectroscopy, Ultima IV, Rigaku Ltd.). The specific surface area (SSA) of the powders was determined by Brunauer, Emmett, and Teller (BET) method from nitrogen adsorption isotherms obtained at $77 \mathrm{~K}$ using an automatic specific surface area analyzer (BELLSORP-mini-II, MicrotracBEL Ltd.). Chemical states of metals and oxide on the surface of the oxide powders were characterized by X-ray photoelectron spectroscopy (XPS) (AXIS-Nova, Shimadzu Kratos Ltd.) using an $\mathrm{Al} \mathrm{K} \alpha$ source, in which the binding energies were calibrated using the $\mathrm{C}_{1 \mathrm{~s}}$ line at $284.6 \mathrm{eV}$. Temperature programmed desorption (TPD) experiments were carried out using a catalyst analyzer (BELCAT-B-SPS, MicrotracBEL Ltd.) as follows. Each sample was evacuated for 15 min at 750 ${ }^{\circ} \mathrm{C}$, then exposed to $50 \mathrm{~mL} / \mathrm{min}$ of oxygen for $1 \mathrm{~min}$ at the same temperature, and cooled to $50{ }^{\circ} \mathrm{C}$ in the same atmosphere. After the evacuation, the sample was heated at a rate of $10{ }^{\circ} \mathrm{C} / \mathrm{min}$ in a helium stream $(30 \mathrm{~mL} / \mathrm{min})$, and desorbed oxygen was monitored by a thermal conducting detector.

\subsection{Preparation of perovskite-type oxide thick films by EPD}

$\mathrm{Sm}_{B \mathrm{O}_{3}}$ modified carbon-felt $\left(\mathrm{SmBO} \mathrm{O}_{3} / \mathrm{CF}\right)$ electrodes were prepared by EPD. ${ }^{(25)}$ A $0.24 \mathrm{~g}$ sample of each oxide powder was suspended in $50 \mathrm{~mL}$ AcAc and mixed in a planetary ball mill (L-P1, Ito Seisakusho Co., Ltd.) at $250 \mathrm{rpm}$ for $30 \mathrm{~min}$. After the ball-mill treatment, $25 \mathrm{mg} \mathrm{I}_{2}$ and $50 \mathrm{~mL}$ AcAc were added to make an EPD electrolyte solution. EPD was carried out using carbon felt (CF; GF-20-2F, Nippon carbon Ltd.) as a working electrode and a Pt plate as a counter electrode. The distance between the two electrodes was fixed at $10 \mathrm{~mm}$. After ultrasonic wave treatment of the EPD electrolyte solution for $30 \mathrm{~min}$, EPD was performed by applying a constant DC voltage at -50 $\mathrm{V}$ vs the Pt electrode for 10 min at room temperature. The $\mathrm{SmBO}_{3} / \mathrm{CF}$ electrodes were washed with ethanol and dried at $100^{\circ} \mathrm{C}$. Further sintering of the electrodes was not carried out. 


\subsection{Electrochemical measurements}

Cyclic voltammetry and amperometric measurements were performed using an electrochemical analyzer (model 1140A, ALS Ltd.) using a Pt plate and an $\mathrm{Ag} / \mathrm{AgCl}(\mathrm{KCl}$ sat.) as the counter and a reference electrodes, respectively. Figure 1 shows a diagram of the sensor electrode using oxide modified carbon felt. All electrochemical experiments were carried out in $50 \mathrm{~mL}$ pH 7.0 Tris$\mathrm{HCl}$ buffer solution at $30^{\circ} \mathrm{C}$ after oxygen or nitrogen bubbling for $30 \mathrm{~min}$. Amperometric sensing properties were measurement by a batch method using solutions of reagent grade $\mathrm{NaNO}_{2}$ or other sodium salts $\left(\mathrm{NaNO}_{3}, \mathrm{Na}_{2} \mathrm{SO}_{4}, \mathrm{Na}_{2} \mathrm{HPO}_{4}, \mathrm{NaHCO}_{3}, \mathrm{CH}_{3} \mathrm{COONa}\right.$, and $\left.\mathrm{NaSCN}\right)$ added dropwise to the analyte solution with a micropipette to control the ion concentrations.

\section{Results and Discussion}

\subsection{Characterization of the oxide powders}

Figure 2 shows the XRD patterns of $\mathrm{SmBO}_{3}(B=\mathrm{Cr}, \mathrm{Mn}, \mathrm{Fe}, \mathrm{Co})$ powders prepared at 750 ${ }^{\circ} \mathrm{C}$ for $2 \mathrm{~h}$ by the polymer precursor method. The powders consisted of primarily single-phase perovskite-type oxide. The SSAs of $\mathrm{SmCrO}_{3}, \mathrm{SmMnO}_{3}, \mathrm{SmFeO}_{3}$, and $\mathrm{SmCoO}_{3}$ were between 1.9 and $8.6 \mathrm{~m}^{2} \mathrm{~g}^{-1}$ as shown in Table 1. SEM images of these powders are shown in Fig. 3. $\mathrm{SmCrO}_{3}$ and $\mathrm{SmCoO}_{3}$ powders were partially sintered and formed large particles as shown by their smaller SSAs. Although $\mathrm{SmMnO}_{3}$ powder consisted of small particles less than $50 \mathrm{~nm}$ in diameter, these particles aggregated partially to form larger particles. Among them, $\mathrm{SmFeO}_{3}$ powder consisted of relatively small particles of ca. $90 \mathrm{~nm}$ in diameter.

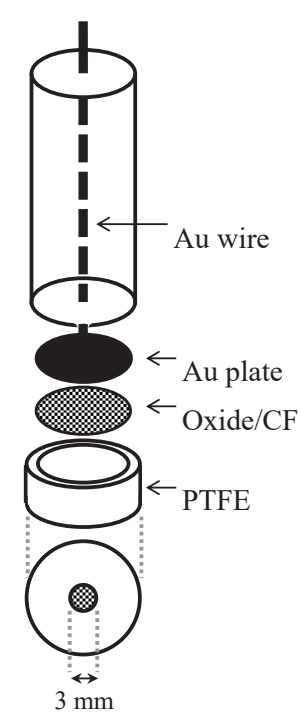

Fig. 1. Schematic diagram of sensor electrode with oxide modified carbon felt.

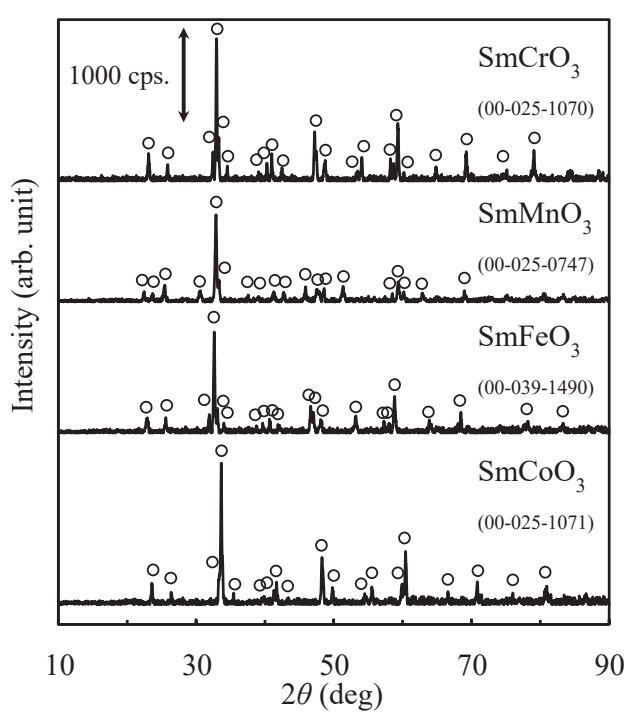

Fig. 2. XRD patterns of $\mathrm{Sm} B \mathrm{O}_{3}$ powders $(B=\mathrm{Cr}$, $\mathrm{Mn}, \mathrm{Fe}, \mathrm{Co}$ ) prepared at $750{ }^{\circ} \mathrm{C}$ for $2 \mathrm{~h}$ (Numbers in the figure are the ICDD numbers of the International Center for Diffraction Data). 
Table 1

BET surface areas, sensor performance for $\mathrm{NO}_{2}^{-}$, and surface oxygen states of $\mathrm{SmBO}_{3}(B=\mathrm{Cr}, \mathrm{Mn}, \mathrm{Fe}, \mathrm{Co})$ powders.

\begin{tabular}{lccccc}
\hline & $\mathrm{SmCrO}_{3}$ & $\mathrm{SmMnO}_{3}$ & $\mathrm{SmFeO}_{3}$ & $\mathrm{SmCoO}_{3}$ & $\mathrm{Fe}_{2} \mathrm{O}_{3}$ \\
\hline BET S.A. $\left(\mathrm{m}^{2} \mathrm{~g}^{-1}\right)$ & 5.0 & 8.6 & 8.3 & 1.9 & - \\
Sensitivity $\left(\mathrm{mA} \mathrm{M}{ }^{-1} \mathrm{~cm}^{-2}\right)$ & 9.9 & 4.3 & 11.9 & 9.4 & 4.5 \\
Linear range $(\mu \mathrm{M})$ & $200-1000$ & $200-900$ & $50-1000$ & $100-800$ & $100-1000$ \\
$O_{\mathrm{A}} /\left(O_{\mathrm{A}}+O_{\mathrm{L}}\right)(\%)^{* *}$ & 43.5 & 36.8 & 46.3 & 44.0 & 14.7 \\
\hline
\end{tabular}

"at $+0.85 \mathrm{~V}$ vs Ag/AgCl.

${ }^{* *} O_{\mathrm{A}}$ : amount of adsorbed oxygen, $O_{\mathrm{L}}$ : amount of lattice oxygen.
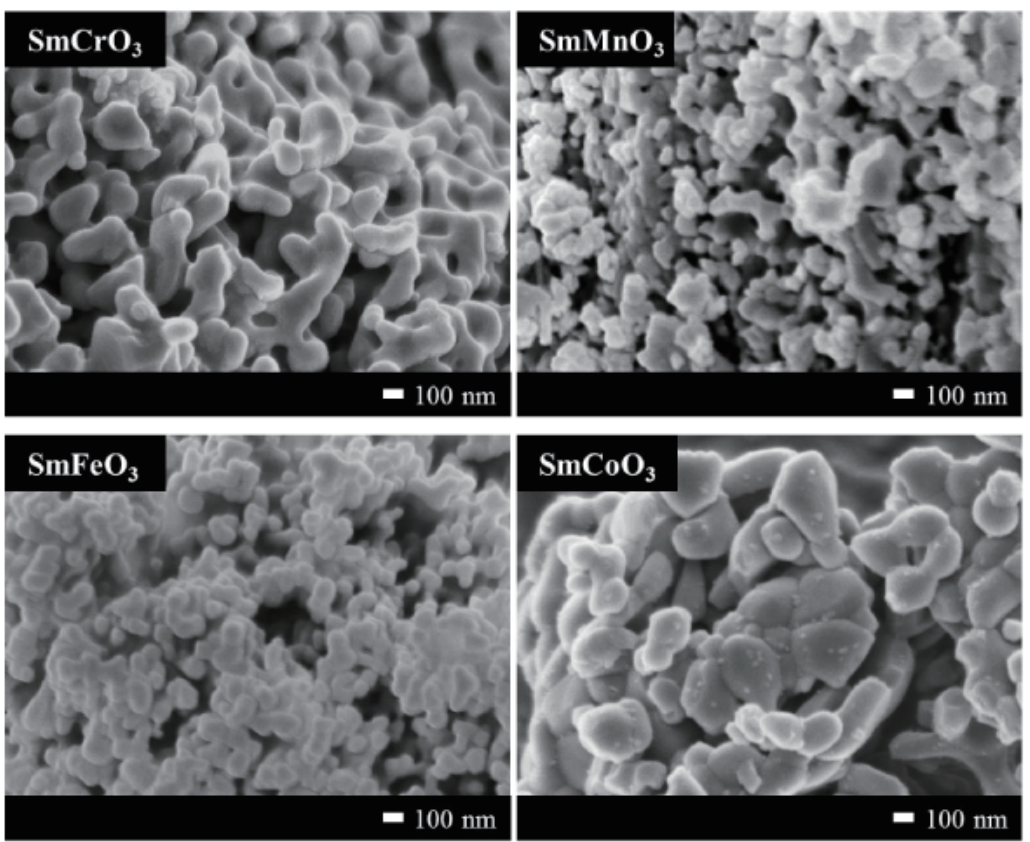

Fig. 3. SEM images of $\mathrm{Sm} B \mathrm{O}_{3}(B=\mathrm{Cr}, \mathrm{Mn}, \mathrm{Fe}, \mathrm{Co})$ powders.

\subsection{Electrochemical measurements}

Figure 4 shows cyclic voltammograms of the $\mathrm{Sm} B \mathrm{O}_{3} / \mathrm{CF}(B=\mathrm{Cr}, \mathrm{Mn}, \mathrm{Fe}, \mathrm{Co})$ electrodes in aqueous solutions at various $\mathrm{NO}_{2}^{-}$concentrations with oxygen bubbling. The cyclic voltammograms in $\mathrm{SmCrO}_{3}, \mathrm{SmMnO}_{3}$, and $\mathrm{SmCoO}_{3}$ systems showed an increase in anodic current depending on $\mathrm{NO}_{2}{ }^{-}$concentration; however, they still had large hysteresis even in a buffer solution. The hysteresis in $\mathrm{SmCrO}_{3}, \mathrm{SmMnO}_{3}$, and $\mathrm{SmCoO}_{3}$ systems should be primarily due to the redox of transition metals $(\mathrm{Cr}, \mathrm{Mn}, \mathrm{Co})$ in the perovskite-type oxides. However, the anodic current of the $\mathrm{SmFeO} 3 / \mathrm{CF}$ electrode around $+0.85 \mathrm{~V}$ vs $\mathrm{Ag} / \mathrm{AgCl}$ increased simply with increasing $\mathrm{NO}_{2}^{-}$ concentration.

Figure 5 shows a typical transient response curve of the $\mathrm{SmFeO}_{3} / \mathrm{CF}$ electrode to various concentration of $\mathrm{NO}_{2}{ }^{-}$at $+0.85 \mathrm{~V}$ vs $\mathrm{Ag} / \mathrm{AgCl}$. The anodic current of the $\mathrm{SmFeO}_{3} / \mathrm{CF}$ electrode increased with increasing $\mathrm{NO}_{2}^{-}$concentration. The $90 \%$ response time from 100 to $200 \mu \mathrm{M}$ was about $3 \mathrm{~min}$. The dependence of response current on $\mathrm{NO}_{2}^{-}$concentration of the $\mathrm{SmFeO}_{3} / \mathrm{CF}$ electrode under $\mathrm{O}_{2}$ and $\mathrm{N}_{2}$ bubbling is shown in Fig. 6. Response currents increased with increasing $\mathrm{NO}_{2}{ }^{-}$concentration with $\mathrm{O}_{2}$ and $\mathrm{N}_{2}$ bubbling. The response current under $\mathrm{O}_{2}$ bubbling was slightly larger than that with $\mathrm{N}_{2}$, especially in the lower concentration range. The $\mathrm{SmFeO}_{3} / \mathrm{CF}$ electrode 

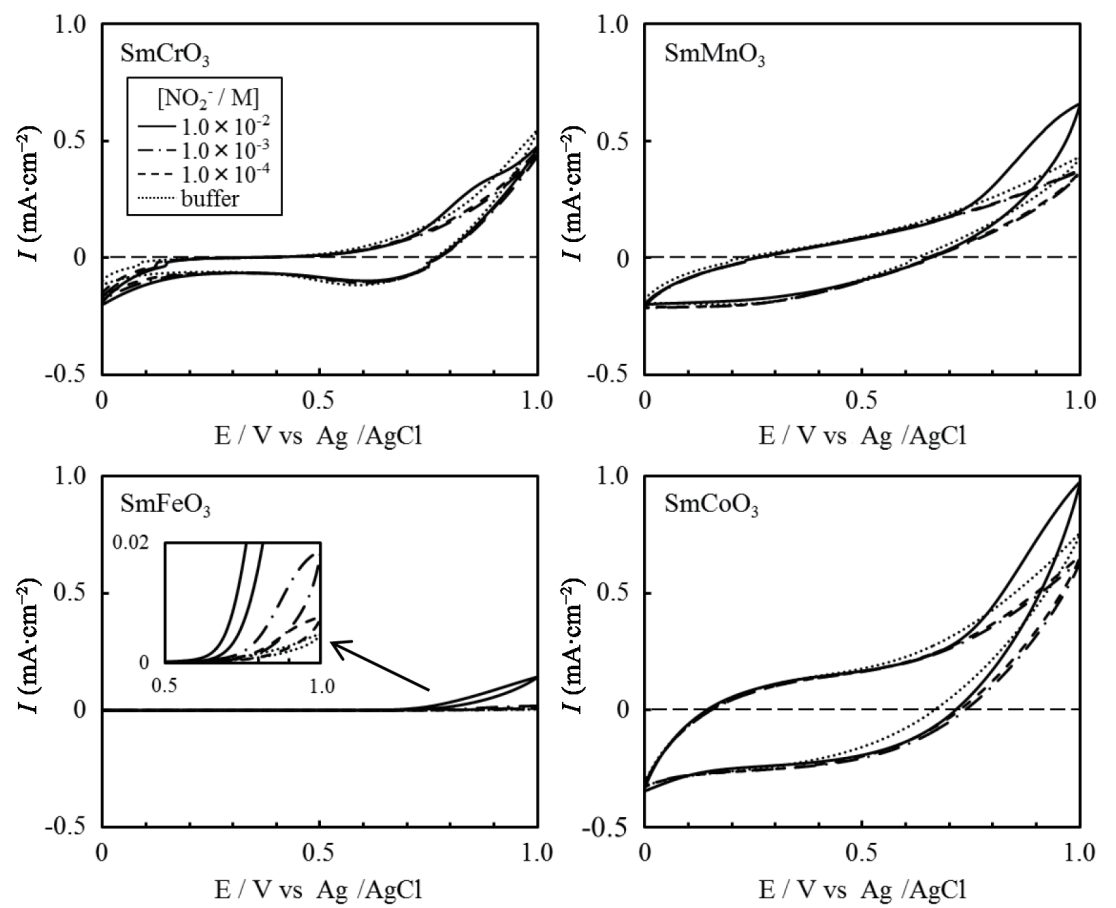

Fig. 4. Cyclic voltammograms of $\mathrm{SmBO} / \mathrm{CF}$ electrodes for various $\mathrm{NO}_{2}^{-}$concentrations (Scan rate: $10 \mathrm{mV} / \mathrm{s}$ ).

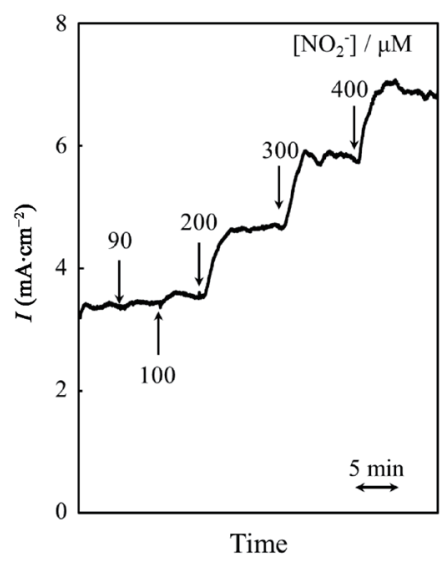

Fig. 5. Response transient curve of the $\mathrm{SmFeO}_{3} / \mathrm{CF}$ electrode to $\mathrm{NO}_{2}^{-}(+0.85 \mathrm{~V}$ vs $\mathrm{Ag} / \mathrm{AgCl})$.

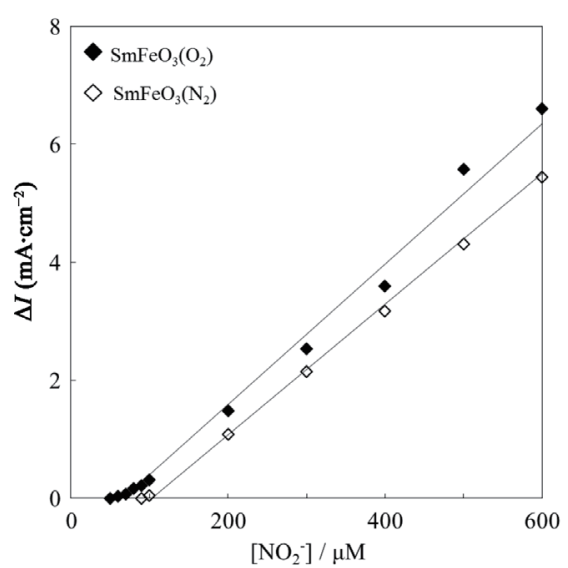

Fig. 6. Dependence of response current on $\mathrm{NO}_{2}$ concentration of the $\mathrm{SmFeO}_{3} / \mathrm{CF}$ electrode with $\mathrm{O}_{2}$ or $\mathrm{N}_{2}$ bubbling $(+0.85 \mathrm{~V}$ vs $\mathrm{Ag} / \mathrm{AgCl})$.

showed a linear sensitivity between $5.0 \times 10^{-5}$ and $6.0 \times 10^{-3} \mathrm{M}$ with a sensitivity of $11.9 \mathrm{~mA} \mathrm{M}^{-1}$ $\mathrm{cm}^{-2}$ under $\mathrm{O}_{2}$ bubbling. This may be related to the reaction with the adsorbed oxygen as described in the following. Hereafter, all response characteristics were measured with $\mathrm{O}_{2}$ bubbling. Figure 7 shows response characteristics of the $\mathrm{Sm}_{B} \mathrm{O}_{3} / \mathrm{CF}(B=\mathrm{Cr}, \mathrm{Mn}, \mathrm{Fe}, \mathrm{Co})$ and $\mathrm{Fe}_{2} \mathrm{O}_{3} / \mathrm{CF}$ electrodes. The $\mathrm{NO}_{2}{ }^{-}$sensitivity for the $\mathrm{Sm} B \mathrm{O}_{3} / \mathrm{CF}$ systems was in the order $\mathrm{SmFeO}_{3}>\mathrm{SmCrO}_{3}>\mathrm{SmCoO}_{3}>$ $\mathrm{SmMnO}_{3}=\mathrm{Fe}_{2} \mathrm{O}_{3}$, as summarized in Table 1. This means that the $\mathrm{SmFeO}_{3}$ perovskite-type structure plays an important role in electrochemical oxidation of $\mathrm{NO}_{2}^{-}$ion. These results also indicated that the Fe surface in the oxides might be the active site for the reaction with $\mathrm{NO}_{2}{ }^{-}$; $\mathrm{Fe}$ in $\mathrm{SmFeO}_{3}$ has higher surface activity for $\mathrm{NO}_{2}^{-}$than $\mathrm{Fe}$ in $\mathrm{Fe}_{2} \mathrm{O}_{3}$. 


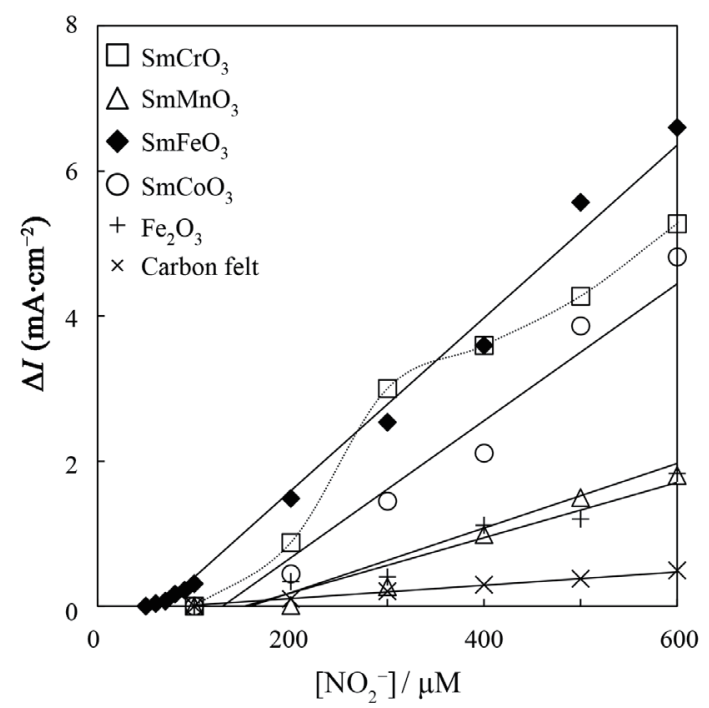

Fig. 7. Dependence of response current on $\mathrm{NO}_{2}^{-}$concentration for various electrodes with $\mathrm{O}_{2}$ bubbling $(+0.85 \mathrm{~V}$ vs $\mathrm{Ag} / \mathrm{AgCl})$.

The $\mathrm{SmFeO}_{3} / \mathrm{CF}$ electrode showed no significant amperometric response at $+0.85 \mathrm{~V}$ vs $\mathrm{Ag} / \mathrm{AgCl}$ for $\mathrm{NO}_{3}^{-}, \mathrm{SO}_{4}{ }^{2-}, \mathrm{HPO}_{4}{ }^{2-}, \mathrm{CH}_{3} \mathrm{COO}^{-}, \mathrm{HCO}_{3}^{-}$, and $\mathrm{SCN}^{-}$anions between 10 and $1000 \mu \mathrm{M}$. Thus, the $\mathrm{SmFeO}_{3} / \mathrm{CF}$ electrode exhibited high selectivity for $\mathrm{NO}_{2}^{-}$.

\subsection{Sensing mechanism}

To investigate the sensing mechanism, surface chemical analysis was carried out by XPS and TPD. First, XPS spectra at $\mathrm{O}_{1 \mathrm{~s}}$ of $\mathrm{Sm}_{B} \mathrm{O}_{3}(B=\mathrm{Cr}, \mathrm{Mn}, \mathrm{Fe}, \mathrm{Co})$ powders were recorded as shown in Fig. 8. Lower and higher binding energy (BE) peaks were identified as lattice oxide $\left(O_{\mathrm{L}}\right)$ and adsorbed oxygen $\left(O_{\mathrm{A}}\right)$, respectively. ${ }^{(26)}$ The $O_{\mathrm{A}} /\left(O_{\mathrm{A}}+O_{\mathrm{L}}\right)$ ratio on the surface of $\mathrm{SmFeO}_{3}$ was the highest among the $\mathrm{SmBO}_{3}$ systems as shown in Table 1. Figure 9 compares XPS spectra between $\mathrm{Fe}_{2} \mathrm{O}_{3}$ and $\mathrm{SmFeO}_{3}$ at $\mathrm{O}_{1 \mathrm{~s}}$ and $\mathrm{Fe}_{2 \mathrm{p}}$. The amount of adsorbed oxygen on $\mathrm{Fe}_{2} \mathrm{O}_{3}$ was very small compared with that on $\mathrm{SmFeO}_{3}$. The $\mathrm{BE}$ of lattice oxygen in $\mathrm{Fe}_{2} \mathrm{O}_{3}$ was relatively large as shown in Fig. 9 (a); thus, $\mathrm{Fe}_{2} \mathrm{O}_{3}$ crystals are characterized by strong metal-oxygen bonding. Oxidation states of $\mathrm{Fe}$ in $\mathrm{Fe}_{2} \mathrm{O}_{3}$ and $\mathrm{SmFeO}_{3}$, included $\mathrm{Fe}^{2+}, \mathrm{Fe}^{3+}$, and $\mathrm{Fe}^{4+}$ as shown in Fig. 9(b). The presence of $\mathrm{Fe}^{2+}$, especially in $\mathrm{SmFeO}_{3}$, should allow the high valence of $\mathrm{Fe}^{4+}$ and/or oxygen vacancies in the oxide.

To investigate the oxygen adsorption-desorption properties of perovskite-type oxides, TPD profiles of the $\mathrm{Sm}_{B \mathrm{O}_{3}}(B=\mathrm{Cr}, \mathrm{Mn}, \mathrm{Fe}, \mathrm{Co})$ powders were determined. As shown in Fig. 10, two peaks appear at around $250{ }^{\circ} \mathrm{C}$ and over $450{ }^{\circ} \mathrm{C}$ in the TPD profiles of the $\mathrm{SmBO}_{3}(B=\mathrm{Cr}, \mathrm{Mn}$, $\mathrm{Fe}, \mathrm{Co}$ ) powders. The former and latter peaks seem to be chemically bonded surface oxygen and lattice oxygen, respectively. ${ }^{(27,28)}$ Oxygen desorption of chemically bonded surface oxygen from the $\mathrm{SmFeO}_{3}$ was noted from ca. $240{ }^{\circ} \mathrm{C}$, which was the lowest observed temperature for the $\mathrm{Sm}_{3 \mathrm{O}} \mathrm{O}_{3}(B$ $=\mathrm{Cr}, \mathrm{Mn}, \mathrm{Fe}, \mathrm{Co}$ ) series. From these TPD and XPS measurements, the surface of the $\mathrm{SmFeO}_{3}$ has the most active oxygen species among the oxides. 


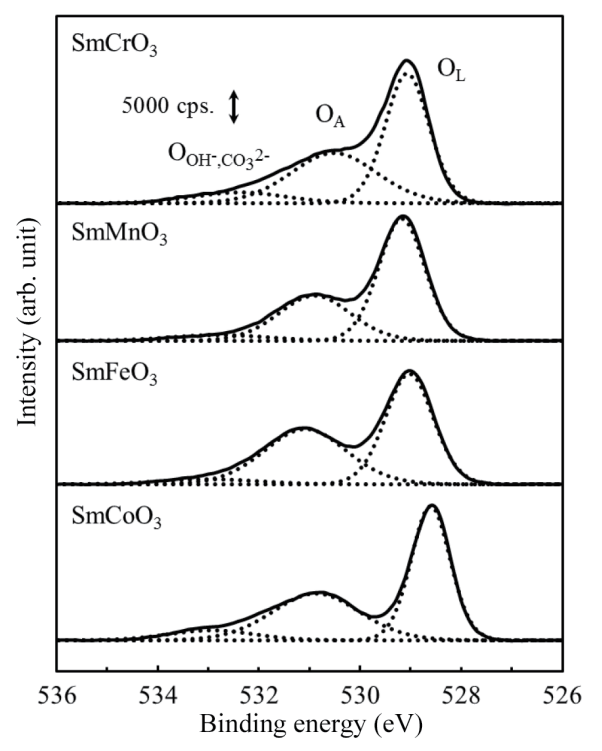

Fig. 8. XPS spectra of $\mathrm{O}_{1 \mathrm{~s}}$ of $\mathrm{Sm}_{3} \mathrm{O}_{3}(B=\mathrm{Cr}, \mathrm{Mn}$, $\mathrm{Fe}, \mathrm{Co}$ ) powders.

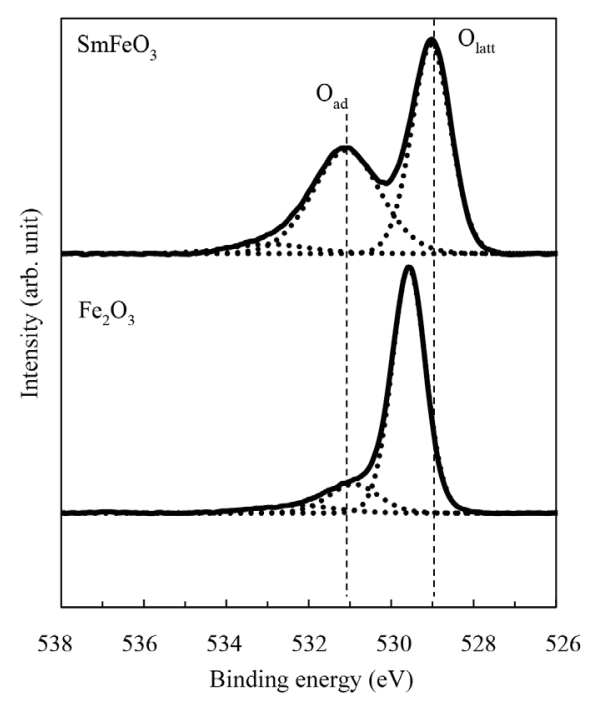

(a)

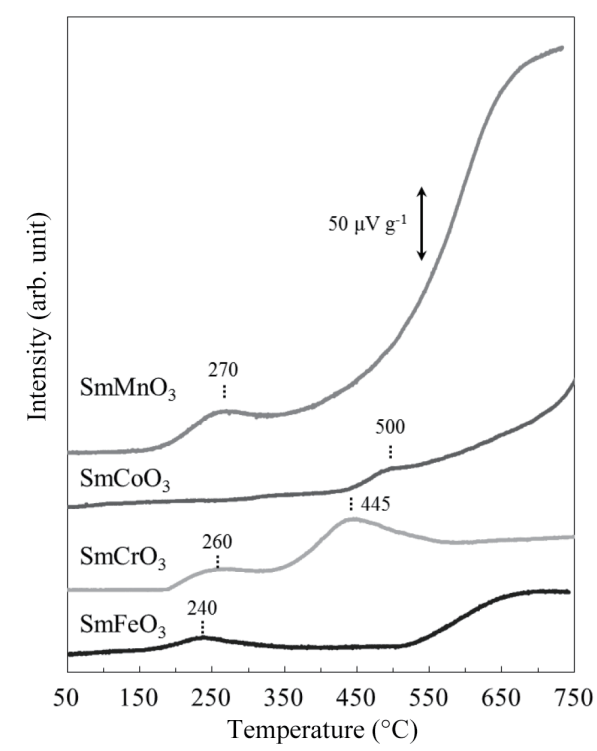

Fig. 10. $\mathrm{O}_{2}$-TPD profiles of $\mathrm{Sm}_{3} \mathrm{O}_{3}(B=\mathrm{Cr}, \mathrm{Mn}, \mathrm{Fe}$, Co) powders.

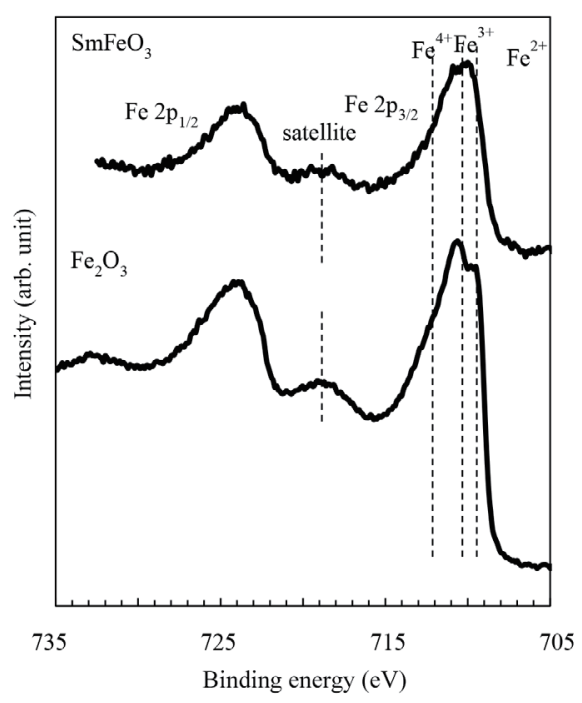

(b)

Fig. 9. XPS spectra of (a) $\mathrm{O}_{1 \mathrm{~s}}$ and (b) $\mathrm{Fe}_{2 \mathrm{p}}$ of $\mathrm{SmFeO}_{3}$ and $\mathrm{Fe}_{2} \mathrm{O}_{3}$ powders.

From these results, the sensing mechanism may be expressed as Eqs. (1) and (2):

$$
\begin{gathered}
\mathrm{SmFeO}_{3}{ }^{-} \mathrm{O}_{\mathrm{ad}}{ }^{-}+\mathrm{H}_{2} \mathrm{O} \rightarrow \mathrm{SmFeO}_{3}-2 \mathrm{OH}_{\mathrm{ad}}{ }^{-} \\
\mathrm{SmFeO}_{3}-2 \mathrm{OH}_{\mathrm{ad}}{ }^{-}+\mathrm{SmFeO}_{3} \mathrm{NO}_{2}{ }^{-} \rightarrow \mathrm{SmFeO}_{3}+\mathrm{NO}_{3}{ }^{-}+2 \mathrm{e}^{-}+\mathrm{H}_{2} \mathrm{O}
\end{gathered}
$$

A possible reaction responsible for $\mathrm{NO}_{2}^{-}$response was proposed to be the oxidation reaction of $\mathrm{NO}_{2}{ }^{-}$by adsorbed $\mathrm{OH}_{\text {ad }}{ }^{-}$on a $\mathrm{Fe}$ site in $\mathrm{SmFeO}_{3}$. The electrtocatalytic activity for $\mathrm{NO}_{2}^{-}$oxidation 
is thought to be influenced by the presence of $\mathrm{OH}_{\mathrm{ad}}{ }^{-}$on the oxide surface which was formed by the reaction between $\mathrm{O}_{\text {ad }}{ }^{-}$and $\mathrm{H}_{2} \mathrm{O}$. In these results, the $\mathrm{SmFeO}_{3} / \mathrm{CF}$ electrode showed higher sensitivity than the $\mathrm{Fe}_{2} \mathrm{O}_{3} / \mathrm{CF}$ or other electrodes.

\section{Conclusions}

The $\operatorname{Sm} B \mathrm{O}_{3}(B=\mathrm{Cr}, \mathrm{Mn}, \mathrm{Fe}, \mathrm{Co})$ powders could be prepared by a polymer precursor method at $750{ }^{\circ} \mathrm{C}$. The $\mathrm{SmBO}_{3}$-modified $\mathrm{CF}$ electrodes were fabricated by an EPD method without sintering. Among the oxides tested, the $\mathrm{SmFeO}_{3} / \mathrm{CF}$ electrode showed the highest $\mathrm{NO}_{2}^{-}$sensitivity, $11.9 \mathrm{~mA}$ $\mathrm{M}^{-1} \mathrm{~cm}^{-2}$, and a wide linear response range between $5.0 \times 10^{-5}$ and $1.0 \times 10^{-3} \mathrm{M}$. Furthermore, the $\mathrm{SmFeO}_{3}$ /carbon electrode showed no response to $\mathrm{NO}_{3}^{-}, \mathrm{SO}_{4}{ }^{2-}, \mathrm{HPO}_{4}{ }^{2-}, \mathrm{CH}_{3} \mathrm{COO}^{-}, \mathrm{HCO}_{3}^{-}$, and $\mathrm{SCN}^{-}$up to $1000 \mu \mathrm{M}$. The high $\mathrm{NO}_{2}^{-}$sensitivity of $\mathrm{SmFeO}_{3}$ arises from the large amount of adsorbed oxygen, which should strongly correlate to the electrocatalytic activity of $\mathrm{NO}_{2}^{-}$oxidation.

\section{Acknowledgements}

The authors are grateful to the Center for Instrumental Analysis, Kyushu Institute of Technology, for the XPS measurements.

\section{References}

1 V. V. Kumar and S. P. Anthony: Anal. Chim. Acta 57 (2014) 842.

2 T. Zhang, H. Fan, and Q. Jin: Talanta 81 (2010) 95.

3 M. Pietrzak and M. E. Meyerhoff: Anal. Chem. 81 (2009) 3637.

4 B. Néel, M. G. Asfhar, G. A. Crespo, M. Pawlak, D. Dorokhin, and E. Bakker: Electroanalysis 26 (2014) 473.

5 M. Eguílaz, L. Agüí, P. Yáñez-Sedeño, and J. M. Pingarrón: J. Electroanal. Chem. 644 (2010) 30.

6 D. Ye, L. Luo, Y. P. Ding, Q. Chen, and X. Liu: Analyst 136 (2011) 4563.

7 S. Yang, X. Zeng, X. Liu, W. Wei, S. Luo, Y. Liu, and Y. Liu: J. Electroanal. Chem. 639 (2010) 181.

8 Y. Zhang, Y. Zhao, S. Yuan, H. Wang, and C. He: Sens. Actuators, B 185 (2013) 602.

9 N. Wang, X. Cao, X. Cai, Y. Xu, and L. Guo: Analyst 135 (2010) 2106.

10 M. Pal and V. Ganesan: Analyst 135 (2010) 2711.

11 H. Mao, X. Liu, D. Chao, L. Cui, Y. Li, W. Zhang, and C. Wang: J. Mater. Chem. 20 (2010) 10277.

12 S. Gupta and R. Prakash: RSC Advances 4 (2014) 7521.

13 C. A. Caro, F. Bedioui, and J. H. Zagal: Electrochim. Acta 47 (2002) 1489.

14 C. Wang, R. Yuan, Y. Chai, S. Chen, Y. Zhang, F. Hu, and M. Zhang: Electrochim. Acta 62 (2012) 109.

15 Y. H. Cheng, C. W. Kung, L. Y. Chou, R. Vittal, and K. C. Ho: Sens. Actuators, B 192 (2014) 762.

16 X. Cao, Y. Xu, and N. Wang: Electrochim. Acta 59 (2012) 81.

17 S. Radhakrishnan, K. Krishnamoorthy, C. Sekar, J. Wilson, and S. J. Kim: Appl. Catal., B 22 (2014) 148.

18 J. Wang, D. Zhao, Y. Zhang, J. Li, and C. Xu: Anal. Methods 6 (2014) 3147.

19 S. Takase, T. Matsumoto, and Y. Shimizu: Electrochemistry 78 (2010) 150.

20 S. Takase, A. Ishikawa, and Y. Shimizu: Electrochemistry 69 (2001) 272.

21 H. Aono, E. Traversa, M. Sakamoto, and Y. Sadaoka: Sens. Actuators, B 94 (2003) 132.

22 T. Tasaki, S. Takse, and Y. Shimizu: Sens. Actuators, B 187 (2013) 128.

23 T. Iseri, M. Kawasaki, S. Takase, and Y. Shimizu: ITE Lett. Batteries New Technol. Med. 5 (2006) 231.

24 Y. Shimizu and T. Murata: J. Am. Ceram. Soc. 80 (1997) 2702.

25 S. Y. Ng and A. R. Boccaccini: Mater. Sci. Eng., B 116 (2005) 208.

26 M. Mori, Y. Iwamoto, M. Asamoto, Y. Itagaki, H. Yahiro, Y. Sadaoka, S. Takase, Y. Shimizu, M. Yuasa, K. Shimanoe, H. Kusaba, and Y. Teraoka: Catal. Today 139 (2008) 125.

27 Y. Teraoka, M. Yoshimatsu, N. Yamazoe, and T. Seiyama: Chem. Lett. 6 (1984) 893.

28 H. M. Xhang, Y. Shimizu, Y. Teraoka, N. Miura, and N. Yamazoe: J. Catal. 121 (1990) 432. 